\title{
Growth of sprat Sprattus sprattus larvae in the German Bight (North Sea) as inferred by otolith microstructure
}

\author{
Pedro Ré, Emanuel Gonçalves \\ Laboratório Marítimo da Guia, Dept de Zoologia e Antropologia, Faculdade de Ciências da Universidade de Lisboa, \\ Estrada do Guincho, P-2750 Cascais, Portugal
}

\begin{abstract}
Growth of sprat larvae was studied in the German Bight of the North Sea and 2 different stations (stratified and mixed water masses) were compared. Sprat larvae were aged using daily growth increments in sagittal otoliths. The daily nature of otolith growth increments was corroborated using the marginal increment technique. The data presented are consistent with the deposition of one complete increment per $24 \mathrm{~h}$ period, indicating that at least larvae with lengths greater than $11.0 \mathrm{~mm}$ form daily growth increments in their otoliths. There was some evidence that daily growth increments are deposited on the otoliths of sprat larvae only after the onset of exogenous feeding. Integrated somatic growth rate was $0.406 \mathrm{~mm} \mathrm{~d}^{-1}$. This value is comparable to others obtained for similar pelagic clupeoid species. There were no significant differences between growth rates at the 2 stations.
\end{abstract}

\section{INTRODUCTION}

The sprat Sprattus sprattus (Linnaeus, 1758) is a small, multiple (batch) spawning species with a protracted spawning season and a large number of spawnings per year (Alheit 1986). The species is pelagic throughout its life history. The newly-hatched larvae are relatively small ( 3 to $4 \mathrm{~mm}$ ) and contain little endogenous energy supply. Larvae are likely to be highly vulnerable to starvation-induced mortality if feeding conditions are not suitable during the early life stages (Shields 1989). Sprat spawns in a wide area of the North Sea, and spawning seems to occur mainly offshore close to the transition between stratified and mixed water masses (frontal zones) (Munk 1991). Alheit et al. (1987) showed that egg distribution is closely associated with temperature (highest egg densities were found in warmer water masses). The main spawning period extends from May to July; however time of peak spawning, relative fecundity and batch fecundity can vary significantly between years (Alheit 1987)

Otolith microstructure examination is now a preferred tool for the study of young fish providing a wealth of information to larval fish ecologists. Applications of information derived from otolith microstructure are numerous: (1) age determination; (2) daily growth rate estimations; (3) mortality; (4) migratory and environmental history; (5) competition; (6) abundance; (7) condition and (8) taxonomy, among others (see Campana \& Neilson 1985 and Jones 1986 for reviews). The quantification of some of these life history parameters is essential for the evaluation of the causes underlying recruitment variability, especially as described by Hjort's (1914) critical period concept, Lasker's (1981) stable ocean hypothesis and Sinclair's (1988) member/vagrant hypothesis.

Understanding the processes affecting recruitment is a fundamental objective in fishery biology. It is commonly assumed that annual recruitment is determined during the early life history stages, particularly the larval and juvenile stages. Houde $(1987,1989)$ showed that variability in growth and mortality rates of marine fish larvae can cause important fluctuations in recruitment levels. Studies of larval otolith microstructure can provide valuable insights into daily growth rate variability both on the individual and population levels. 
Larval condition is normally assessed using various methods [e.g. RNA/DNA ratios: Clemmesen (1988); histological indices: Theilacker (1986); morphological indices: Frank \& McRuer (1989); lipids: Håkanson (1989); enzymes: Ueberschär (1988); elemental composition: Ehrlick (1974); otoliths: Methot (1981), Suthers et al. (1989)]. Otolith microstructure has been shown to be sensitive to both environmental change and ontogenetic transitions during the first developmental stages. In this context it can be used to infer the dynamics of larval growth, particularly the identification of stressful periods, and is considered to reflect important past events during the early life history (Ré 1986b). Variation in the width of daily growth increments from otoliths of field-captured specimens can be analyzed for correlations with the timing of particular developmental (ontogenetic) and environmental (ecoethological) events to determine their relative importance (e.g. Suthers et al. 1989).

Sprat larvae were sampled over the German Bight during a cruise of the FS 'Victor Hensen' (2 to 9 June 1990). The main objectives of this cruise were: (1) to carry out a restricted regional survey of planktonic and hydrographic conditions in the German Bight for selection of representative sites for detailed sampling; (2) to deploy Argos drifting buoys at selected stations to allow repeated sampling of the same water body; (3) to sample and preserve sprat larvae for a range of condition analyses over $24 \mathrm{~h}$ periods to investigate diel changes in condition; (4) to carry out concurrent micro-

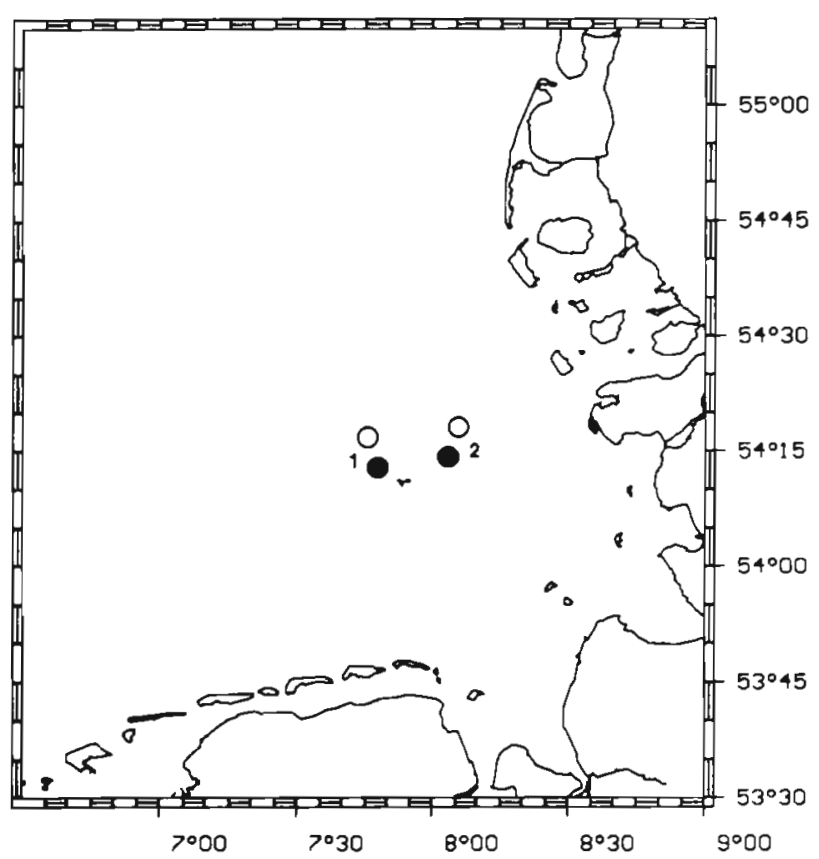

Fig. 1. Positions of $24 \mathrm{~h}$ stations. (O): Start and finish positions respectively of the Argos buoys zooplankton sampling and hydrographic investigations to describe the feeding environment of sprat larvae; (5) to take depth stratified plankton samples over $24 \mathrm{~h}$ to describe the vertical migration pattern of sprat larvae and their preys. This cruise coincided with the beginning of the European SARP ('Sardine and Anchovy Recruitment Project') (Anon. 1983, 1990) programme, including studies on larval sprat Sprattus sprattus in the German Bight, sardine Sardina pilchardus (Walbaum, 1792) off the north coast of Spain and anchovy Engraulis encrasicolus (Linnaeus, 1758) within Portuguese estuaries.

The main objectives of the present work were to study growth of sprat larvae in the German Bight of the North Sea, sampling from 2 different stations (stratified and mixed water masses), as inferred from otolith daily growth increments and to relate otolith microstructure to some transitions during the first developmental stages.

\section{MATERIAL AND METHODS}

Sprat larvae were sampled in the German Bight of the North Sea. Sampling was mainly restricted to 2 contrasting stations (stratified and mixed water masses) (Fig. 1). Selection of these stations was based on the results of Undulator (Aiken 1981) tows. The Undulator consists of a small hydrodynamic towed body with a servo-controlled diving fin enabling it to follow a saw-tooth dive (up to $60 \mathrm{~m}$ depth) and climb profile, while towed behind the survey vessel. Inside the Undulator is a solid state data logger which records sensor signals at intervals of $5 \mathrm{~s}$, including measurements of temperature, conductivity and pressure.

All samples of sprat larvae were taken by means of relatively slow (approximately 3 knots towing speed) double oblique tows, from the surface to near the bottom, using a $50 \mathrm{~cm}$ high speed tow net (Beverton \& Tungate 1967) fitted with a $280 \mu \mathrm{m}$ mesh aperture filtering net. Following selection of a station, for each 24 h sampling sequence a sub-surface drogued Argos buoy was released to enable sampling to follow the same water mass. Before deploying the Argos buoy several samples were taken with the above-described net, over a northwest transect, out from the German Bight and around areas with different hydrographic conditions, in order to identify suitable localities for the $24 \mathrm{~h}$ stations and to study sprat larval growth.

The first $24 \mathrm{~h}$ station (Fig. 1) was located close to a frontal boundary where salinity increased from $33.35 \%$ at the surface to over $34 \%$ at $20 \mathrm{~m}$ depth temperature decreased from 12.75 to $11.25^{\circ} \mathrm{C}$ over the same depth range. Overall drift of the buoy was to the north (Fig. 1) with semi-diurnal east and west excur- 
sions. The second station (Fig. 1) was in relatively well mixed shallow water inshore of the frontal region in water of around $32 \%$ salinity and $13.3^{\circ} \mathrm{C}$ temperature. Tidal drift as indicated by the Argos buoy was a series of tidal ellipses with a net northwards displacement. On Stn 1 the Argos buoy had to be relocated due to the possibility that its northerly track was over-influenced by the southerly winds (sampling was for a 24 h period and extended for 12 further h). At Stn 2 samples were taken during a $17 \mathrm{~h}$ period.

A total of 77 samples were taken for otolith microstructure analysis. On completion of a haul some sprat larvae were sorted from the catch and immediately fixed with $5 \%$ formalin buffered with borax ( $\mathrm{pH} 8.5$ to 9) (Ré 1983a). Other sprat larvae were measured to the nearest $0.1 \mathrm{~mm}$ under a binocular microscope and fixed over either desiccant or liquid nitrogen within 15 min for condition analysis (respectively elemental composition and lipids) (Coombs \& Håkanson 1991) or under other preservatives for different condition analysis (RNA/DNA, histochemistry).

Sprat larvae were aged using daily growth increments in sagittal otoliths. The methods used for obtaining, mounting and observing the sagittae were described by Ré (1983a, 1986a). Microgrowth increments were counted with the aid of a compound optical microscope using a magnification of $1000 \times$. Several counts were made for each sagitta, and the number obtained more often was chosen. The mean of the counts of both otoliths from each larvae was used for data analysis. Otoliths unsuitable for examination due to some reason (unclear microstructure or deficiency in the preparation) were discarded (4.5\%). All otolith measurements were taken under the microscope using a calibrated micrometer eyepiece. A total of 768 sprat otoliths were studied belonging to 473 individual larvae. Larval lengths were measured with the aid of a binocular microscope to the nearest $0.5 \mathrm{~mm}$ by placing the larva on a transparent grid marked in millimetres and illuminated from below. Larval lengths were corrected for shrinkage using the equation prepared by Theilacker (1980) for Engraulis mordax. All larval lengths correspond to standard lengths corrected for shrinkage.

The daily nature of otolith growth increments was corroborated using the marginal increment technique described by Ré (1984). The time of completion of an increment and the periodicity of increment formation was determined following the change of the relative widths of the last 2 increments in relation to time of day. These widths were measured with the aid of a Sony video camera fitted to a compound microscope and connected to a television screen obtaining a magnification of $3740 \times$. The measurements were taken with the aid of a calliper on the television screen. Marginal increments could only be analyzed on sagittae from larvae greater than approximately $11.0 \mathrm{~mm}$ length. Otolith increments from smaller larvae were too narrow to confidently measure the relative widths of marginal increments.

Integrated growth of sprat larvae was estimated from the relationship between body size and the number of daily growth increments enumerated from the otoliths.

A Video-Microscope-IBM/PC image analysis system (IAS) was used for the study of sprat larval otolith microstructure. The IAS used consisted of a IBM compatible microcomputer, a Sony video camera, a video monitor, image analysis software (Image-Pro Plus software) and hardware (digitizer board PCVISIONplus) interfaced with a compound optical microscope. This IAS was used mainly to measure the widths of daily growth increments and to study otolith microstructure using its image processing capabilities.

\section{RESULTS}

The changes in the index of completion of the marginal increment over the $24 \mathrm{~h}$ period are represented in Fig. 2. A total of 315 otoliths were measured. The data presented are consistent with the deposition of one complete increment per $24 \mathrm{~h}$ period, indicating that at least larvae with lengths greater than $11.0 \mathrm{~mm}$ form daily growth increments in their otoliths. The deposition of a new daily growth increment occurred between 21:30 and 02:00 h (local time). Values of $100 \%$ for the index of completion were found during this period (Fig. 2). The initiation of the deposition of the discontinuous zone (terminology of Mugiya et al. 1981) occurred around the onset of the dark period between 20:30 and 00:00 h (local time). The incremental zone was deposited during the rest of the $24 \mathrm{~h}$ period.

Yolk-sac larval otoliths were examined for the occurrence of growth increments. Typical growth incre-

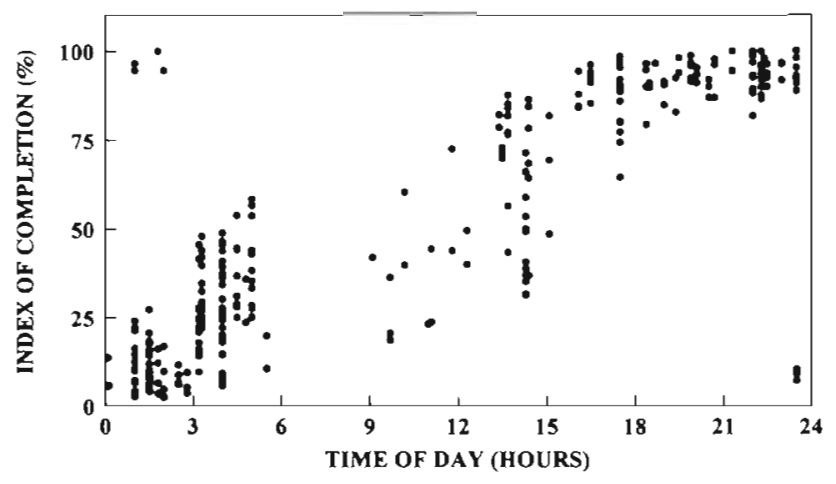

Fig. 2. Sprattus sprattus. Diel change in the index of completion of the marginal increment in the sagittae of sprat larvae $(\mathrm{n}=315)$ (see text for details) 


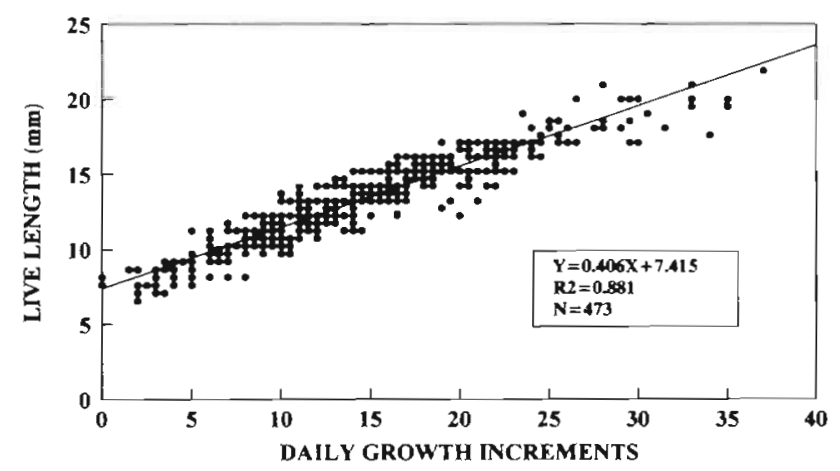

Fig. 3. Sprattus sprattus. Relationship between the number of daily growth increments (age post-yolk absorption) on sagittae and live length, together with linear regression analysis and fitted line

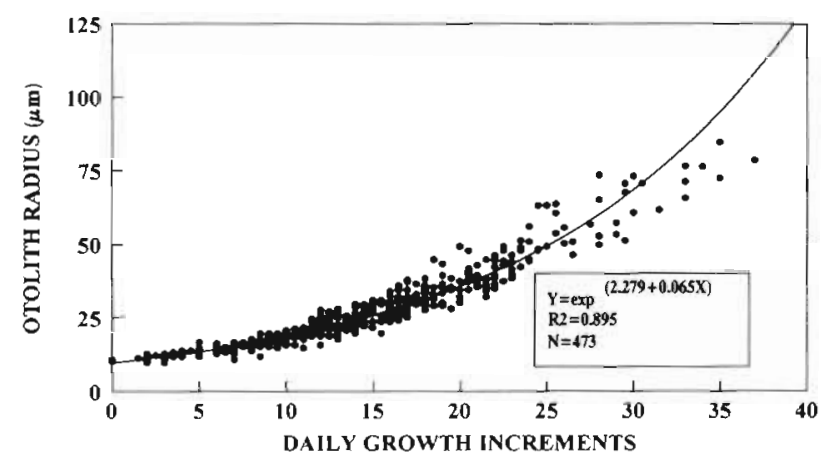

Fig. 4. Sprattus sprattus. Relationship between number of daily growth increments and otolith radius, together with exponential regression analysis and fitted curve

ments composed of dark discontinuous and light incremental zones when viewed under a microscope with transmitted light could only be discerned in sagittae belonging to older larvae with functional mouths, pigmented eyes and little or no remaining yolk. This evidence is consistent with the deposition of daily growth increments only after the onset of exogenous feeding, which occurs $6 \mathrm{~d}$ after hatching at a temperature of $15^{\circ} \mathrm{C}$ (Alshuth 1988). The start of daily increment formation at first feeding has been reported for other clupeoid larvae (e.g. Brothers et al. 1976, Ré 1984, 1987). Furthermore the radius of the first observed discontinuous zone (presumably first feeding check) is similar to the radius of the otolith from late-yolk-sac larvae or first feeding larvae. The average radius of the first feeding check was $10.88 \mu \mathrm{m}(\mathrm{SD}=0.76, \mathrm{n}=469)$. Under the assumption that sprat larvae deposit one growth increment in their sagittae with a $24 \mathrm{~h}$ periodicity, the chronological ages (post-hatching age) can be determined by adding 6 to $7 \mathrm{~d}$ (temperature dependent yolk-sac period) to the number of rings enumerated from the otoliths
Integrated growth of sprat larvae in the German Bight could be adequately described using linear regression analysis up to a post-yolk absorption age of approximately $40 \mathrm{~d}$ (Fig. 3). Average (integrated) daily growth of sprat larvae (total number of aged larvae sampled at the 2 stations and surrounding areas) was $0.406 \mathrm{~mm} \mathrm{~d}^{-1}$ (Fig. 3).

The relationship between the number of daily growth increments and otolith radius was fitted with an exponential curve (Fig. 4). Sagittal daily growth increments had different widths and were clearly

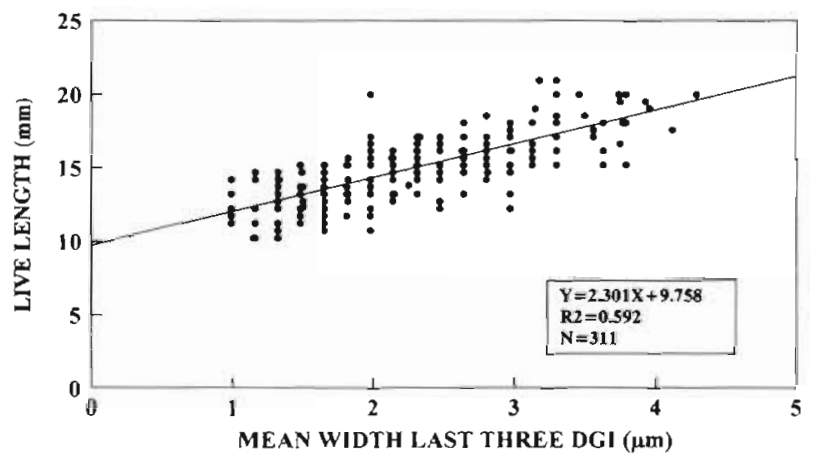

Fig. 5. Sprattus sprattus. Relationship between mean width of the last 3 daily growth increments (DGI) and live length, together with linear regression analysis and fitted line
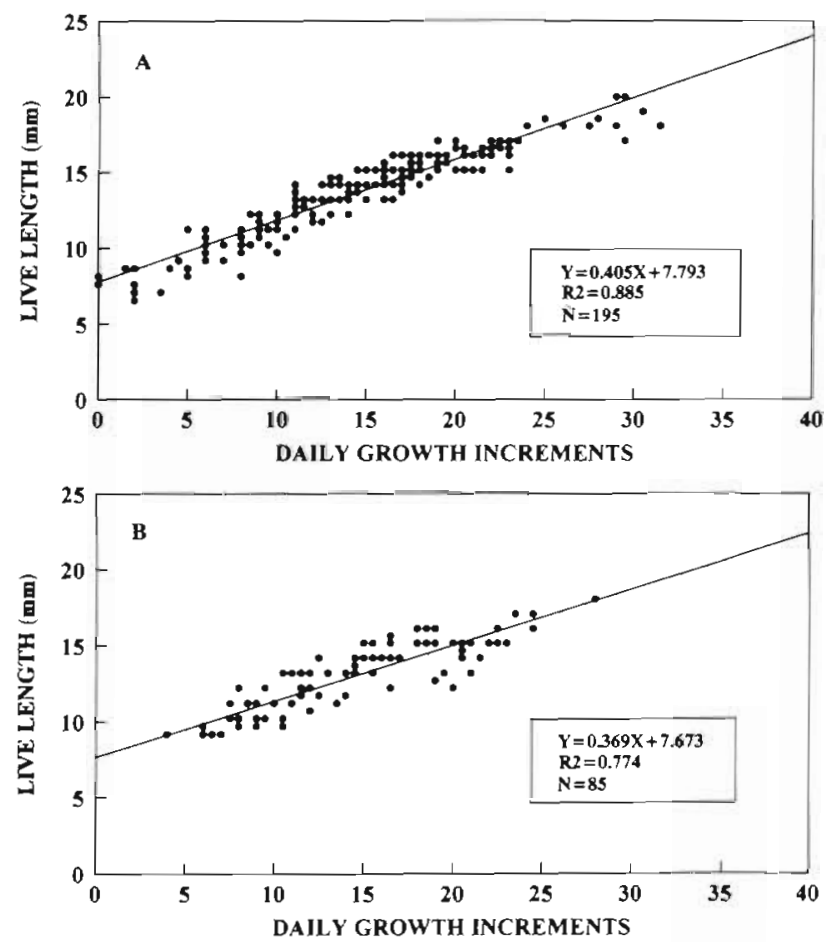

Fig. 6. Sprattus sprattus. Relationship between number of dally growth increments and live length, together with linear regression analysis and fitted line at: (A) Stn 1 (stratified waters); (B) Stn 2 (mixed waters) 
wider close to the border of the otolith in older larvae (see below). The mean width of daily growth increments varied from 0.40 to $2.33 \mu \mathrm{m}$ (mean $=1.18, \mathrm{SD}=$ $0.34, \mathrm{n}=463$ ) and was greater in larger larvae. The width of the last 3 daily growth increments varied from 0.99 to $4.29 \mu \mathrm{m}$ (mean $=$ 2.16, $\mathrm{SD}=0.70, \mathrm{n}=311$ ) and increased linearly with live length (Fig. 5).

There were no significant differences between the radius of left and right sagittae (Wilcoxon test, $Z=$ $1.933, \mathrm{p}>0.05, \mathrm{n}=29$ ) or between the number of daily growth increments enumer-

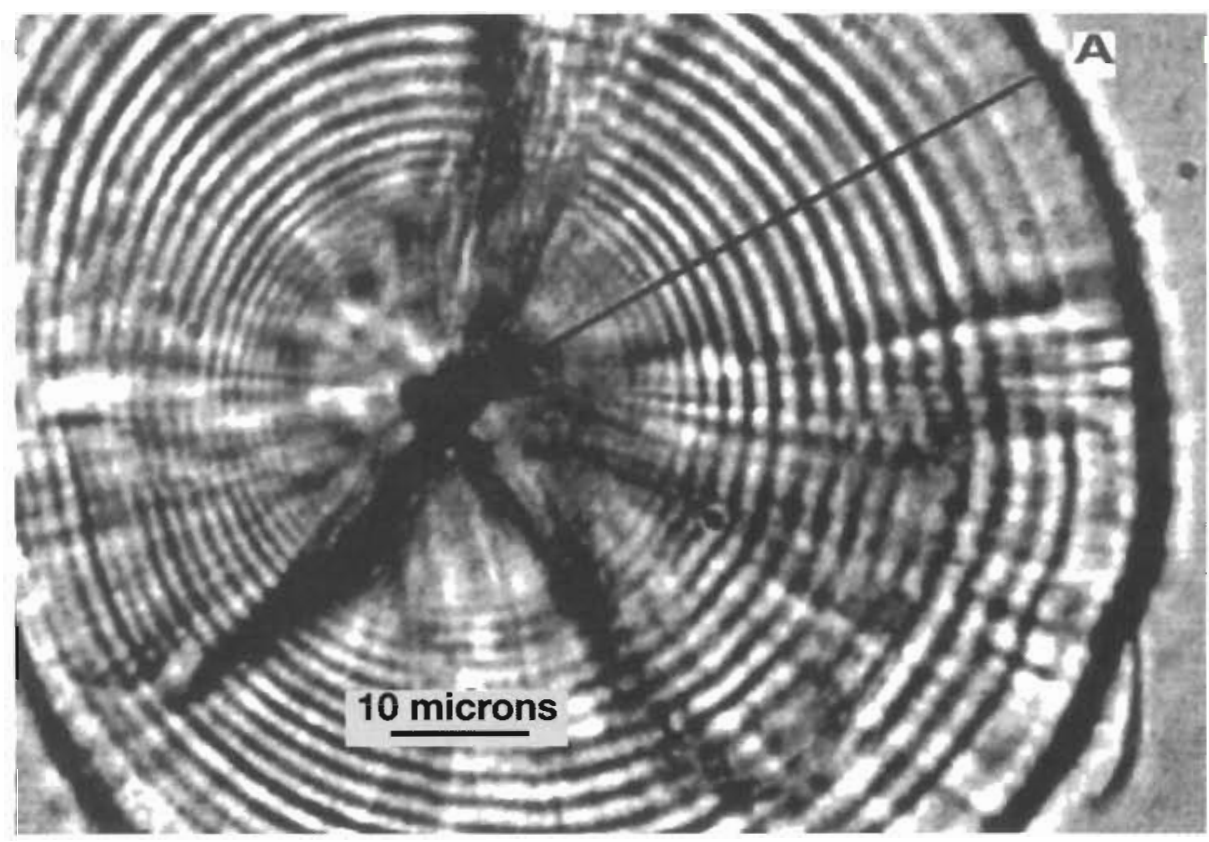
ated from left and right sagittae (Wilcoxon test, $Z=1.550, \mathrm{p}>0.05, \mathrm{n}=29$ ).

Larval lengths $3 \mathrm{~d}$ before sampling was back-calculated using the relationship between otolith radius and live length. The linear regression computed for daily growth versus live length was not significant $\left(\mathrm{r}^{2}=\right.$ $0.012, \mathrm{n}=299, \mathrm{p}>0.05$ )

Integrated growth rates of larval sprat sampled in stratified and mixed sites were very similar $(0.405$ and $0.369 \mathrm{~mm} \mathrm{~d}^{-1}$ respectively) (Fig. 6). There were no significant differences found between the slopes of the regression lines at stratified and mixed sites (ANCOVA, $F=2.421, \mathrm{p}>0.05$ ).

On a given otolith the widths of daily growth increments can vary significantly. The first 6 to 10 daily growth increments are fainter and narrower in comparison with subsequent increments that are wider and sharper up to an age of $40 \mathrm{~d}$ (Figs. 7 \& 8).

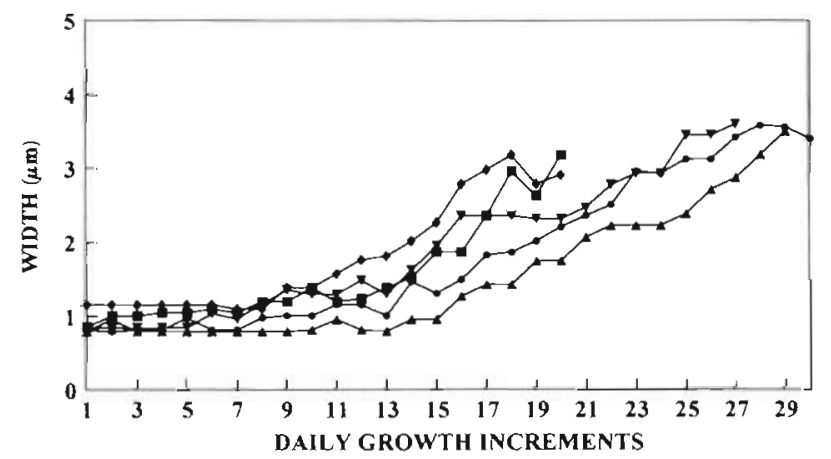

Fig. 7. Sprattus sprattus. Widths of daily growth increments in 5 larval otoliths

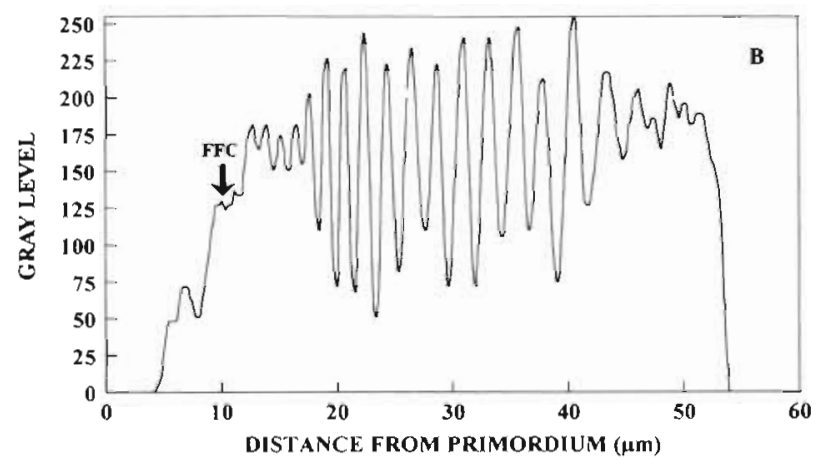

Fig. 8. Sprattus sprattus. (A) Larval otolith (processed image) (standard length of larva $15.5 \mathrm{~mm}$ ). (B) Gray scale index at each pixel along the line indicated in (A). Discontinuous (black) and incremental (white) zones of each daily growth increment are shown $(0=$ black, $255=$ white $)$. FFC: first feeding check

\section{DISCUSSION}

Alshuth (1988) studied the deposition of microgrowth increments in the sagittae of laboratory-reared sprat larvae. This author notes that increments were first observed $6 \mathrm{~d}$ after hatching at the time of first feeding and complete absorption of the yolk-sac. The increments were formed under a daily rhythm for a period of $29 \mathrm{~d}$. Strangely enough this author did not find any variation in the relationship between counts of increment number and age in days (standard deviation of the mean was $0, n=86$ ). Shields (1989) showed that increment deposition rate was daily in late larval and juvenile stages of sprat. This author also observed that 
multiple feedings per day did not disrupt the daily increment formation, but intermittent feeding altered the appearance of juvenile increments and resulted in sub-daily increment counts in larvae. Intermittent feeding caused variability in the contrast of individual increments and faint increments formed during nonfeeding days were unreadable, resulting in an underestimation of age. Shields (1989) also notes that growth-dependent variation in the otolith-size/fishsize relationship was evident, invalidating the back calculation of age-specific growth rates from increment widths. This author emphasised, however, that such variation provides the potential for the relatively rapid comparison of population growth history.

The present study corroborated the daily nature of otolith growth increments using the marginal increment technique described by Ré (1984). The data presented are consistent with the deposition of one complete increment per $24 \mathrm{~h}$ period, indicating that at least larvae with lengths greater than $11.0 \mathrm{~mm}$ form daily growth increments in their otoliths. There was some evidence that daily growth increments are deposited on the otoliths of sprat larvae only after the onset of exogenous feeding.

The smallest increment measured as well as mean widths of daily increments were clearly above the functional resolution limit of light microscopy (the majority of daily growth increments had widths $\geq 1 \mu \mathrm{m}$ ) suggesting that unresolved increments (Campana et al. 1987) were not a problem in this study.

Integrated somatic growth rate in the whole studied area was $0.406 \mathrm{~mm} \mathrm{~d}^{-1}$. This value is comparable to others obtained for similar pelagic clupeoid species (e.g. Methot \& Kramer 1979, Ré 1986a, Leak \& Houde 1987). Shields (1989) also found integrated somatic growth rates that varied from 0.37 to $0.49 \mathrm{~mm} \mathrm{~d}^{-1}$ for sprat larvae in the Irish Sea. There were no significant differences in growth rates found at contrasting sites (stratified and mixed) suggesting that growth could be limited by food availability among other factors. A similar situation is referred by Ré (1983b) for sardine larvae.

Munk (1991) investigated the daily growth of sprat larvae in the eastern North Sea. This author found significant differences in growth rate of larvae in relation to their distance from a frontal zone implying that best conditions for larval growth and survival may be located close to this zone.

The back-calculations of age-specific growth rates from increment width measurements has been widely recognised as a powerful application of microstructure analysis. Growth back-calculations require a constant relationship between otolith and fish growth (an unchanging relationship between otolith size and fish size is assumed). Recent studies, however, indicate that the manner in which otolith growth is related to fish growth is complex (many studies have shown a growth rate effect, whereby slow-growing fish have relatively large otoliths in relation to fish size) (see Secor et al. 1989 and Campana 1990 for reviews). Individual daily growth rates can be calculated and averaged over $3 \mathrm{~d}$ to allow for some delayed response of otolith growth to changes in somatic growth (Methot 1981). For these reasons back-calculation studies should take into account the individual variability in what concerns somatic and otolith growth. In our study no significant relationship was found between daily growth (averaged over the last $3 \mathrm{~d}$ ) and live length. Negative values found for estimated growth rates were associated to the variability of back-calculated fish size from otolith size.

Sprat larval otolith shows a similar microstructure to other clupeoid larvae (e.g. sardine and anchovy: Ré $1986 \mathrm{~b})$. The microstructure of larval otoliths can be related to certain life history events. Two main transitions were recognized. The deposition of the first daily growth increment was related to the onset of exogenous feeding. The transition between fainter and sharper increments can probably be related to rhythms of swim bladder inflation/deflation, rhythms of feeding and vertical migration. Taking into account that otolith microstructure studies provide the only mean of obtaining with a certain degree of precision individual fish growth histories, it can constitute a new tool for determining larval condition. Further studies are needed to elucidate the relationship between larval growth and hydrographical and biological parameters.

Acknowledgements. The present work forms part of a European SARP (Sardine and Anchovy Recruitment Project) programme. Financial support has been provided in part through EC funding by contract No. MA.1.96. During the present work E.G. was supported by a grant from JNICT (BD/872/90IG). The authors acknowledge the assistance of all participants in the cruise. We are also indebted to Steven Campana, Erlend Moksness and 2 anonymous reviewers for critical reading of the manuscript.

\section{LITERATURE CITED}

Aiken, J. (1981). The undulating oceanographic recorder mark 2. J. Plankton Res 3:551-560

Alheit, J. (1986). Reproductive biology of sprat, Sprattus sprattus: factors determining annual egg production. Comm. Meet. int. Coun. Explor. Sea C.M.-ICES/H:58, p. 16

Alheit, J. (1987). Variation of batch fecundity of sprat, Sprattus sprattus, during spawning season. Comm. Meet. int. Coun. Explor. Sea C.M.-ICES/H:44, p. 9

Alheit, J., Whal, E., Cichangir, B. (1987). Distribution, abundance, development rates, production and mortality of sprat eggs. Comm. Meet. int. Coun. Explor. Sea C.M.ICES/H:45, p. 17

Alshuth, S. (1988). Daily growth increments on otoliths of lab- 
oratory-reared sprat, Sprattus sprattus L., larvae. Meeresforsch. 32: 23-29

Anon. (1983). Workshop on the IREP component of the IOC program on Ocean Science in Relation to Living Resources (OSLR). Intergovernmental Oceanographic Commission, Workshop Report no. 33, UNESCO, Parrs

Anon. (1990). Second IOC workshop on Sardine/Anchovy Recruitment Project (SARP) in the Southwest Atlantic Intergovernmental Oceanographic Commission, Workshop Report no. 65, UNESCO, Paris

Beverton, R. H. J., Tungate, D. S. (1967). A multipurpose plankton sampler. J. Cons. int. Explor. Mer 31. 145-157

Brothers, E. B., Mathews, C. P., Lasker, R. (1976). Daily growth increments in otoliths from larval and adult fishes Fish. Bull. U.S. 74: 1-8

Campana, S. E. (1990). How reliable are growth backcalculation based on otoliths? Can. J. Fish. Aquat. Sci. 47 2219-2227

Campana, S. E., Gagné, J. A., Munro, J. (1987). Otolith microstructure of larval herring (Clupea harengus): image or reality?. Can. J. Fish. Aquat. Sci. 44: 1922-1929

Campana, S. E., Neilson, J. D. (1985). Microstructure of fish otoliths. Can. J. Fish. Aquat. Sci. 42: 1014-1032

Clemmesen, C. M. (1988). A RNA and DNA fluorescence technique to evaluate the nutritional condition of individual marine fish larvae. Meeresforsch. 32: 134-143

Coombs, S. H., Hakanson, J. L. (1991). Diel variation in lipid and elemental composition of sprat (Sprattus sprattus) larvae at mixed and stratified sites in the German Bight of the North Sea. Comm. Meet. int. Coun. Explor. Sea C.M.ICES/L: 49 , p. 11

Ehrlick, K. F. (1974). Chemical changes during growth and starvation of herring larvae. In: Blaxter J. H. S. (ed.) The early life history of fish. Springer-Verlag, Berlin, p. 301-323

Frank, K. T., McRuer, J (1989). Nutritional status of fieldcaptured haddock (Melanogrammus aeglefinus) larvae from south western Nova Scotia: an assessment based on morphometrics and vertical distribution data. Can. J. Fish Aquat. Sci. 46: 125-133

Håkanson, J. L. (1989). Condition of larval anchovy (Engraulis mordax) in the Southern California Bight, as measured through lipid analysis. Mar. Biol. 102: 153-159

Hjort, J. (1914). Fluctuations in the great fisheries of northern Europe. Rapp. P. -v. Réun. Cons perm. int. Explor. Mer 20 : $1-228$

Houde, E. D. (1987). Fish early dynamics and recruitment variability. Am. Fish. Soc. Symp. 2: 17-29

Houde, E. D. (1989). Comparative growth, mortality, and energetics of marine fish larvae: temperature and implied latitudinal effects. Fish. Bull. U.S. 87: 471-495

Jones, C. (1986). Determining age of larval fish with the otolith increment technique. Fish. Bull. U.S. 84: 91-103

Lasker, R. (1981). The role of a stable ocean in larval fish survival and subsequent recruitment. In: Lasker, R. (ed.) Marine fish larvae. University of Washington Press, Seattle, p. $80-88$

Leak, J. C., Houde, E. D. (1987). Cohort growth and survival of bay anchovy Anchoa mitchilli larvae in Biscayne Bay, Florida. Mar. Ecol. Prog. Ser. 37: 109-122

Methot, R. D. (1981). Spatial covariation of daily growth rates of larval northern anchovy, Engraulis mordax, and northern lampfish, Stenobrachius leucopsarus. Rapp. P.-v. Réun. Cons. int. Explor. Mer 178: 424-431

Methot, R. D., Kramer, D. (1979). Growth of northern anchovy, Engraulis mordax, larvae in the sea. Fish. Bull. U.S. 77: $413-423$

Mugiya, Y., Watabe, N., Yamada, J., Dean, J. M., Dunkelberger, D. G., Shimizu, M. (1981). Diurnal rhythm in otolith formation in the goldfish, Carassius auratus. Comp. Biochem. Physiol. 68A: 659-662

Munk, P. (1991). Growth and drift pattern of larval sprat (Sprattus sprattus) in the eastern North Sea investigated by otolith microstructure analysis. Comm. Meet. int. Coun. Explor. Sea C.M-ICES/L:36, p. 11

Ré, P. (1983a). Daily growth increments in the sagitta of pilchard larvae, Sardina pilchardus (Walbaum, 1792) (Pisces: Clupeidae). Cybium 7: 9-15

Ré, P. (1983b). Growth of pilchard larvae Sardina pilchardus (Walbaum, 1792) in relation to some environmental factors. Investigación pesq. 47: 277-283

Ré, P. (1984). Evidence of daily and hourly growth in pilchard larvae based on otolith growth increments, Sardina pilchardus (Walbaum, 1792). Cybium 8: 33-38

Ré, P. (1986a), Ecologia da postura e da fase planctónica de Sardina pilchardus (Walbaum, 1792) na regiāo central da costa portuguesa. Bolm Soc. port. Ciênc. nat. 23: 5-81

Ré, P. (1986b). Otolith microstructure and the detection of life history events in sardine and anchovy larvae. Ciênc. Biol. Ecol. Syst. 6: 9-17

Ré, P. (1987). Ecology of the planktonic phase of the anchovy, Engraulis encrasicolus (L.), within Mira estuary (Portugal). Investigación pesq. 51.581-598

Secor, D. H., Dean, J. M., Baldevarona, R. B. (1989). Comparison of otolith growth and somatic growth in larval and juvenile fishes based on otolith/fish length relationships. Rapp. P.-v. Réun. Cons, int. Explor Mer 191: $431-438$

Shields, R. J. (1989). Studies of growth and nutritional status in 0-group sprat, Sprattus sprattus (Clupeidae), using otolith microstructure and lipid analysis techniques. Ph.D. thesis, University of Wales, Bangor

Sinclair, M. (1988). Marine populations. An essay on population regulation and speciation. University of Washington Press, Seattle, p. 252

Suthers, I. A., Frank, K. I., Campana, S. E. (1989). Spatial comparison of recent growth in postlarval atlantic cod (Gagus morhua) off Southern Nova Scotia: inferior growth in a presumed nursery area. Can. J. Fish. aquat. Sci. 46 : $113-124$

Theilacker, G. H. (1980). Changes in body measurements of larval northern anchovy, Engraulis mordax, and other fishes due to handling and preservation. Fish. Bull. U.S 78: $685-692$

Theilacker, G. H. (1986). Starvation-induced mortality of young sea-caught jack mackerel Trachurus symetricus, determined with histological and morphological methods. Fish. Bull U.S. $84: 1-17$

Ueberschär, B. F. R. (1988). Determination of the nutritional condition of individual marine fish larvae by analyzing their proteolytic enzyme activities with a highly sensitive fluorescence technique. Meeresforsch. 32: 144-154 